\title{
Detection of Antiplatelets Antibody Specially GPIIb/IIIa using MIAPA Method in Baghdad Patients with ITP
}

\author{
Baan A. Mtashar ${ }^{1}$, Zeyad A. Shabeeb ${ }^{2}$, Zainab F. Ashoor ${ }^{3}$ \\ ${ }^{1}$ Msc. Microbiology \\ ${ }^{2}$ (Ph.D Immunology) \\ ${ }^{3}(\mathrm{Ph} . \mathrm{D}$ Immunology)
}

\begin{abstract}
Immune thrombocytopenic purpura (ITP), is an autoimmune disease that caused by sensitization of platelets by autoantibodies leading to increase platelet destruction mainly by spleen macrophages. Methods: This study has determined and characterized the antiplatelet glycoproteins in Adult patients with ITP. Fifty patients, who were hospitalized with clinical signs of ITP in national center of hematology during 6 months, went under our clinical studies in a research project. ELISA and MAIPA (Monoclonal

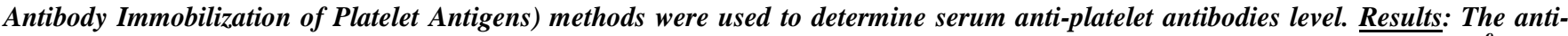
platelet antibodies level above mean $+3 S D$ of control group was assumed as positive. The platelet counts ranged between $0 \times 10^{9} / L$ and $115 \times 10^{9} / \mathrm{L}$. Among the patients $52 \%$ of them were anti-platelet antibodies positive with ELISA method.. Antibody against platelet GPIIb/IIIa using MAIPA method were 28\%, Conclusion: MAIPA is the specific method for the detection of antibody against glycoprotein antigens, it has the advantage of differentiating between immune and non-immune thrombocytopenia.
\end{abstract}

Keywords: Anti-platelet antibody,gpIIb/IIIa , ELIZA, MAIPA

\section{Introduction}

Immune thrombocytopenia purpura (ITP) is an autoimmune disease characterized by loss of self tolerance leading to the production of auto antibodies directed against platelet antigens ${ }^{(1)}$

The autoantibodies produced against platelet glycoproteins are able to bind to platelet membranes, initiating pathways that result in dysfunction and destruction of platelets and clinical singes. These include pethechiae, ecchimosis, and bleeding in some patients ${ }^{(2)}$. Around $85 \%$ of platelet autoantigens lie on the platelet GPIIb/IIIa, GPIb/IX or GP $\mathrm{Ia} / \mathrm{IIa}$ complexes, and $15 \%$ of them are found on other membrane glycoproteins ${ }^{[3]}$

The pathophysiology is complex and the concepts surrounding the mechanisms of thrombocytopenia have shifted from the traditional view of increased platelet destruction mainly by the splenic macrophages and mediated by platelet autoantibodies to associated impaired platelet production and $\mathrm{T}$ cell-mediated effects. Platelet autoantibodies are involved both in peripheral destruction and impaired platelet production. They may impair megacaryocyte development, induce apoptosis, impede platelet release, or promote intramedullary phagocytosis ${ }^{(4-5)}$

However, despite many studies on antiplatelet antibodies, characterization of binding and estimation of anti-platelet auto antibodies remain poor ${ }^{[6]}$ and many questions remain unanswered $^{[1]}$. The aim of our study is to determine and characterized the anti-platelet antibodies in adult patient with ITP with MIPA method and procedures.

\section{Material and Method}

This study was carried out at the National Center of Hematology Al Mustansiriyah University / Baghdad. Fifty patients attended to this center were diagnosed, registered and followed up by specialists. The study was performed during the period from October 2012- March 2013. All the patients were diagnosed as Chronic ITP on proper therapeutic Protocol of prednisolone and Immuran, with history of disease from few months to several years. Fifty apparently healthy subjects with normal platelet count, age and gender matched to the patients group were included in this study.

Five $\mathrm{ml}$ of blood sample was obtained from each patient by vein puncture, three $\mathrm{ml}$ was poured to non-heparinized plain tube and then centrifuged at $3000 \mathrm{RPM}$ for $5 \mathrm{~min}$ to separate serum then labeled and store at $-80^{\circ} \mathrm{C}$ until use.

\section{Platelets Preparation}

Blood from group $\mathrm{O}$ donor in to EDTA were taken.Centrifuged at $1000 \mathrm{rpm}$ for $10 \mathrm{~min}$ in bench top centrifuge.Then Removed the top $3 / 4$ of the Plasma rich platelets ( PRP) from the top of tube and transfer to $10 \mathrm{ml}$ conical centrifuge tube. PAS/EDTA( $\mathrm{PH}=7)$ buffer were added to $10 \mathrm{ml}$ and centrifuged at 4000rpm for $5 \mathrm{~min}$. Decanted supernatant and re-suspended in $2 \mathrm{ml}$ buffer.

\section{Anti-platelet antibodies detection}

ELISA plate was coated with $100 \mu \mathrm{L}$ of platelet lysate (200 $\mu \mathrm{g} / \mathrm{ml}$ ) and incubated at $4{ }^{\circ} \mathrm{C}$ overnight. The following day plate was centrifuged at $1500 \mathrm{rpm}$ for 5 minutes. After washing, $100 \mu \mathrm{L}$ of diluted patients and controls sera (1:10 diluted in PBS with $1 \%$ BSA) were added and the plate was 


\section{International Journal of Science and Research (IJSR) \\ ISSN (Online): 2319-7064 \\ Index Copernicus Value (2013): 6.14 | Impact Factor (2015): 6.391}

incubated for an hour at $37^{\circ} \mathrm{C}$. The unbound anti-platelet antibodies were removed by washing four times with TBST. Hundred $\mu \mathrm{L}$ Goat anti human HRP-conjugated antibody (1: 30000 diluted in PBS), the optional dilution was modified after experimented more than one dilution, was added to each well and incubated at RT for an hour. The plate was washed five times with washing buffer (TBST) then $100 \mu \mathrm{L}$ of substrate [Tetramethylbenzidine (TMB) sigma] was added and the plate incubated for 30 min in a dark place. The reaction was stopped by adding $100 \mu \mathrm{L}$ of $3 \mathrm{M} \mathrm{HCL}$, and the OD was measured at $620 \mathrm{~nm}$.

\section{Monoclonal Antibody Immobilization of Platelet Antigens (MAIPA)}

ELISA plate was coated with $100 \mu \mathrm{L}$ of Goat anti mouse IgG [final concentration $5 \mathrm{ug} / \mathrm{ml}$ diluted in Carbonate Bicarbonate Buffer (CBB) $\mathrm{pH} 8.6$ in each well and incubated overnight at $4^{\circ} \mathrm{C}$. After washing with Tris Buffer Saline (TBS), the plate was blocked with $200 \mu \mathrm{L}$ of $3 \%$ BSA in PBS and incubated for an hour at room temperature (RT). Hundred $\mu \mathrm{L}$ of washed $\mathrm{O}$ negative platelets suspension containing $100 \times 109 / \mathrm{L}$ were added to the tubes which were blocked with $50 \mu \mathrm{L} 3 \%$ BSA and incubated for an hour with $100 \mu \mathrm{L}$ of patients and controls serum for an hour at $37^{\circ} \mathrm{C}$. Forty $\mu \mathrm{L}$ of each monoclonal mouse anti platelet glycoproteins [ IIb/IIIa, Ib/IX and IIa/Ia with final concentration of $20 \mu \mathrm{g} / \mathrm{ml}$ diluted in PBS were added to the individual tubes containing mixture of washed platelets and patients or controls sera and incubated at $37^{\circ} \mathrm{C}$ for 30 minutes. The unbound human anti platelet-glycoproteins were removed by washing three times with (TBST washing buffer). Hundred $\mu \mathrm{L}$ of lysis buffer were added to each tube and incubated for 30 minutes at $37^{\circ} \mathrm{C}$. After centrifuging all tubes at $1500 \mathrm{rpm}$ for 30 minutes at $4^{\circ} \mathrm{C}$, $100 \mu \mathrm{L}$ of supernatant was added to each well which were coated with anti-mouse antibody and incubated at $4^{\circ} \mathrm{C}$ for 90 minutes. The plate was washed four times with washing buffer and $100 \mu \mathrm{L}$ of Goat antihuman HRP conjugated antibody (1: 30000 diluted in PBS) was added to each well and incubated at RT for an hour. The plate was washed five times with washing buffer. $100 \mu \mathrm{L}$ of substrate (TMB) was then added and the plate incubated for $30 \mathrm{~min}$ in a dark place. The reaction was stopped by adding $100 \mu \mathrm{L}$ of $3 \mathrm{M}$ $\mathrm{HCL}$, and the OD was measured at $650 \mathrm{~nm}$.

\section{Calculation of the result}

The mean controls absorbance was used as normal value. We also used the mean controls with three standard deviation $($ mean+3SD) as the cut-off. The anti-platelet antibodies level of each sample above the cut off was assumed as antibody positive.

\section{Statistical Analysis}

All data were analyzed using the SPSS, version 22 software. Statistical analysis included descriptive statistics (frequency tables), T-Test, and Spearman correlation (r). P value which is . 0.05 was considered statistically significant.

\section{Result}

In this project the goal of our study is to determine antiplatelet GPs antibody in Adult with ITP. 50 patients and 50 healthy individuals were included in our study controls. $72 \%$ of patients were female and $28 \%$ Male and their age ranges between ( $17-68$ ) years. The clinical signs were variable including 15 individuals only with petechiae, 11 of them not only with petechiae, but also with purpura and 8 of them with ecchymosis signs, and finally 4 of them were found out with severe bleeding from gums .patient were treated with prednislone and some of them with Immuran.

Table 1 shows more details about Patients and control characteristic.

Table 1: Patient and control characteristic

\begin{tabular}{|c|c|c|}
\hline Parameter & Patients & control \\
\hline Number & 50 & 50 \\
\hline Age ( mean ) & 40 & 40 \\
\hline Gender & & \\
\hline Male : No. $(\%)$ & $14(28)$ & $15(30)$ \\
\hline Female: No.(\%) & $36(72)$ & $35(70)$ \\
\hline Platelets count $\times 10^{9 /} 1($ mean $)$ & 52 & 235 \\
\hline Antiplatelets antibody ( mean) & 0.43 & 0.17 \\
\hline
\end{tabular}

Table 2 shows more details about platelet count in patients.

Table 2: The platelet count in patients

\begin{tabular}{|c|c|}
\hline Platelets count $\times 10^{9} / 1$ & Number \\
\hline$<10 \times 10^{9} / 1$ & 4 \\
\hline $10-30 \times 10^{9} / 1$ & 9 \\
\hline $31-90 \times 10^{9} / 1$ & 28 \\
\hline$>90 \times 10^{9} / 1$ & 8 \\
\hline
\end{tabular}

\section{The determination of anti-platelet antibodies:}

The results with ELISA indicated that anti-platelet antibodies in sera of all patients and controls, The mean controls absorbance was used as normal value. We also used the mean controls antibody level with three standard deviation $($ mean+3SD) as the cut-off. The anti-platelet antibodies level of each sample above the cut off was assumed as antibody positive ${ }^{(2)}$.

Out of 50 patients, $52 \%$ had anti-platelet antibody positive with mean platelet count of $35 \times 10^{9} / \mathrm{L}$. using t- test, it was statistically shown that there was a significant diffrences between ITP patients and control group $(p=0.001)$ Table 3 shows the anti- platelet antibodies in ITP patients. Figure 1 shows anti platelet antibody in groups and when we use the sperman correlation between antiplatelets antibody showed there was significant correlation $(r=-0.66, p=<0.001)$

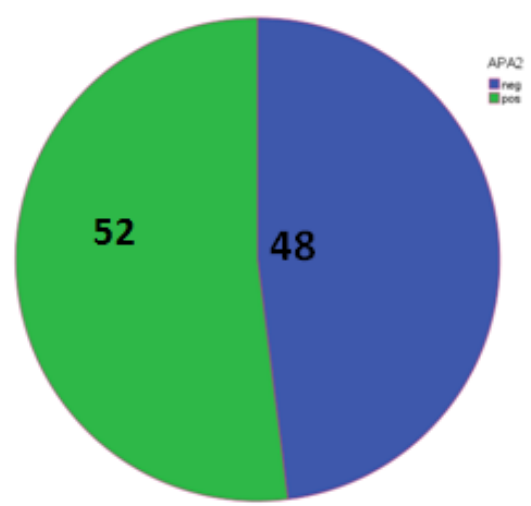

Figure 1: Shows the anti- platelet antibodies in groups . 


\section{International Journal of Science and Research (IJSR) \\ ISSN (Online): 2319-7064}

Index Copernicus Value (2013): 6.14 | Impact Factor (2015): 6.391

Table 3: Compare between ITP patients \& healthy control in relation to Total anti platelets antibody mean .

\begin{tabular}{|c|c|c|c|c|}
\hline p-value & $\begin{array}{c}\text { Control } \\
\mathrm{n}=50\end{array}$ & \multicolumn{2}{|c|}{ ITP Patient $\mathrm{n}=50$} & Parameter \\
\hline$<0.001 * *$ & $0.17 \pm 0.05$ & $0.43 \pm 0.28$ & Mean \pm SD & $\begin{array}{c}\text { Total Anti } \\
\text { platelet } \\
\text { antibody }\end{array}$ \\
\hline \multicolumn{4}{|c|}{$*(\mathrm{P}<0.05), * *(\mathrm{P}<0.01)$, NS: Non-significant. } \\
\hline
\end{tabular}

\section{Anti gpIIb/IIIa IgG antibody}

Using MAIPA method, antibodies in patients' sera were analyzed against three most important platelet glycoproteins ( GPIIb/IIIa ) result shown Out of 26 ( $52 \%$ ) ITP patients were positive total antiplatelet antibodies there were $8(30.7 \%)$ positive Anti gpIIb /IIIa IgG antibody.

\section{Discussion}

ITP is an autoimmune disease characterized by platelet destruction, which can result in increased bleeding and haemorrhage ${ }^{[6,7]}$. For further characterization function of auto antibodies against platelet glycoproteins in ITP patients, our study has indicated, first of all the determination of anti-platelet antibodies using ELIZA method, then the detection of anti gpIIb/IIIa antibodies by MAIPA.

During our study period, 50 adult patient with ITP clinical symptoms were studied. The result of our clinical studies indicated that major signs were petecheaia and purpura with minor signs of severe bleeding. The age variety was between 17 to 68 years. The platelet count showed that more than $26 \%$ of patients had platelet count $<30 \times 10^{9} / \mathrm{L}$, $74 \%$ had a persistent platelet count $<150 \times 10^{9} / \mathrm{L}$, but only $20 \%$ had a count $<20 \times 10^{9} / \mathrm{L}$.

Fifty normal voluntary adults were used as the normal controls and the main result of anti-platelet antibodies + 3SD (Mean + 3SD) was used as the cut off, and ITP patients who their anti-platelet antibodies were above the cut off line placed with patients with antibody positive. It was found that $52 \%$ out of 26 patients in our assay were anti-platelet antibodies positive with the main platelets count $35 \times 10^{9} / \mathrm{L}$ which show a good correlation between decreasing circulated platelets and increasing antibodies, compare with anti-platelet negative patients. In some cases there were not relations between anti-platelet antibodies and platelet account. This could be due to the acute phase of disease which their platelets absorbs antibodies and removes these platelet sensitivities from circulation by phagocyte system. In the other hand, detection of auto antibodies on platelet surface due to platelet structure is not simple ${ }^{[8]}$. However, using the platelet lysate as source of platelet antigens, $52 \%$ of patients were antibodies positive. It is suggested that in the platelet lysate perhaps, the conformational structure of platelet glycoproteins was changed, resulting in not expression of more platelet antigens [9]. We employed MAIPA technique to detect anti-platelet glycoproteins. The results showed that $28 \%$ of patients were anti-GPIIb/IIIa positive. The correlation between this antibody and antibodies against whole platelets was 0.13 .
Hamidpour M. and college's reported that $48 \%$ out of 47 , ITP patients were anti-GPIIb/IIIa positive. Finally, the pathogenèses and diagnoses of ITP has proven complex and concours with several issues such as: genetic predisposition, underlying autoimmune repertoire, inhibition of platelet production, perturbations of cell mediated affector and effector pathways, se-questered harbors within lymphoid organs, and responsiveness to intervention ${ }^{[10]}$.

\section{Conclusion}

MAIPA is the specific method for the detection of antibody against glycoprotein antigens, could be used to differentia between immune and non-immune thrombocytopenia

\section{Acknowledgment}

The authors wish to thank all the Doctors and staff members of The National Center of Hematology for their kind and valuable assistance.

\section{References}

[1] Banchette V. Bolton - Maggs P. Childhood Immune thrombocytopenic purpura : Diagnosis and Mangment. HematolOncol/Clin N Am 2010; 24 : 249 - 237

[2] Hamidpour M., Khalili G., Kamali M, Arzani MH , Jadali F, Majd HA, Khojasteh N. Detection of AntiPlatelet Glycoprotein Antibodies Using MAIPA Method. Journal of Paramedical Sciences (JPS) 2010; $\mathrm{V}(3): 17-21$

[3] Harrington W.J, Minnich V, Hollingsworth J.W \& Moore C.V. Demonstration of a thrombocytopenic factor in the blood of patients

[4] Cines DB, Bussel JB, Liebman HA, LuningPrak ET (2009) The ITP syndrome: pathogenic and clinical diversity. Blood 113:6511-6521

[5] Cooper N, Bussel J (2006) The pathogenesis of immune thrombocytopaenic purpura. Br J Haematol 133:364374

[6] Imbach P, Kühne T, Müller D, Berchtold W, Zimmerman S, Elalfy M, Buchanan GR. Childhood ITP: 12 months follow-up data from the prospective registry I of the Intercontinental Childhood ITP Study Group (ICIS). Pediatr Blood Cancer 2006; 46: 351-6.

[7] Imbach P, Kühne T, Müller D, Berchtold W, Zimmerman S, Elalfy M, Buchanan GR. Childhood ITP: 12 months follow-up data from the prospective registry I of the Intercontinental Childhood ITP Study Group (ICIS). Pediatr Blood Cancer 2006; 46: 351-6.

[8] Stavrou E, McCrae KR. Immune Thrombocytopenia in Pregnancy. HematolOncolClin North Am 2009; 23: 1299-1316.

[9] Meyer O, Agaylan A, Bombard S, Kiesewetter H, Salama A. A novel antigen-Specific capture assay for the detection of platelet antibodies and HPA-1a phenotyping. VoxSanguinis 2006; 91: 324-330.

[10] Cines DB, Cuker A, Semple JW. Pathogenesis of immune thrombocytopenia. Presse Med 2014; 43: e4959. 